\title{
Increasing the Burned Time and Mechanical Properties with New Mix As Flame Retardant Based in Hexametaphosphate of Sodium and Borax in Textile $100 \%$ Acrylic Fabrics
}

\author{
M. Olvera-Gracia ${ }^{1}$, L. Mercado-Velazquez ${ }^{1}$, A.M. Paniagua-Mercado ${ }^{2}$ \\ ${ }^{1}$ Instituto Politécnico Nacional, ESIT - Sección de estudios de Posgrado e investigación, Av. IPN, México \\ ${ }^{2}$ Instituto Politécnico Nacional, ESFM - Departamento de Ciencia de Materiales, México \\ Email: manoloolvera@yahoo.com.mx
}

Received 2012

\begin{abstract}
It has been worked with textile fabrics of Acrylic 100\%, that have as final use the Tapestry, this fabrics have been impregnated with a two products flame retardant: Commercial Retardant, which is formed by a combination of a resin polymeric and acid phosphoric and Borax $\left(\mathrm{Na}_{2} \mathrm{~B}_{4} \mathrm{O}_{5}(\mathrm{OH})_{4} \bullet 8 \mathrm{H}_{2} \mathrm{O}\right)$ with Sodium Hexametaphosphate $\left(\mathrm{Na}_{16} \mathrm{P}_{14} \mathrm{O}_{43}\right)$. These Retardants has the advantage of the fact that it can be applied to the substrates mixed with water in the relation 1:1, 1:2 or pure. In order to reduce the flammability, Textile fabrics are coated with flame retardants. The flame retardant capabilities, mechanical properties and structural characteristics of the textile fabrics before and after the use of these products were investigated throughout the special textile methods for inflammability and mechanical resistibility. After the use of the flame retardants the mechanical properties of the fabrics were improved or at least remained the same as compared to fabrics without any treatment. The use of Borax / Sodium Hexametaphosphate /Water results in the essential increase of combustion retardation time about 2 minutes as compared with 8 seconds for untreated fabrics.
\end{abstract}

Keywords: Acrylic; Borax; Flame Retardants; Sodium Hexametametaphosphate; Textile Fabrics

\section{Introduction}

Flame retardants in their various forms have been used in passive protection of timber and other building materials, including metal structures in many textiles and synthetic fibers, as well in a wide variety of technical applications of plastics, mainly in the electronics industry $[1,2]$. Flame retardants can be incorporated into a material either as active or as additives ones. The active components are incorporated into the polymeric structure of some types of plastics. This method is preferred because it produces more stable and uniform properties. Additives are also cheaper and versatile. However, they have the disadvantage to modify the properties of base materials. This is the case of the polybrominated flame retardants, which usually of view are applied as coatings or mix during the processing of materials such as plastics and fibers [3,4].

From a technical standpoint, the effectiveness of fireproof coating is based on two fundamental aspects in depending on type of fibers. In natural fibers, as cotton and wool, it is important to maintain their properties such as of touch, comfort, etc., which do not have other heat-resistant fibers, the durability of retardant effect against washing, the use and a competitive cost. In synthetic fibers, the possibility of fireproof material limits the importance of the application in the dyeing, which only has the effectiveness in blends with natural fibers, because of the strength of the effect brought by the incorporation of the additive mass versus fixation by impregnation $[5,6]$.

Regarding fireproof coating for synthetic fibers, the main interest is treatment of polyester fibers not only due to their commercial importance, either alone or in blend with other fibers, but also because of the obtained success with this fiber at flame retardant treatment as compared with other synthetic fibers [7].

Extreme flammability of the acrylic fibers is caused by strong exothermic reaction of pyrolysis that takes place at temperature of $300^{\circ} \mathrm{C}$ for most commercial variants. This reaction gives rise to the formation of flammable nitriles and monoxide carbon. In order to control this reaction it is possible to add a flame retardant to the fiber for appreciably promotion the carbonization $[8,9]$. The replacement of acrylic fibers by fireproof modacrylic ones is often useful, but this replacement has the disadvantage because of a very high cost of these fibers. This is the reason why there is interest of application of fireproof coating for this type of fibers to retard of flame and at the same time this coating must not affect the mechanical properties of fabrics impregnated.

\section{Experimental Procedure}

Two flame retardant products based on Borax and Sodium Hexametaphosphate was used in order to coat textile fabrics with the composition $100 \%$ acrylic. Also the textile fabrics were coated with a commercial flame retardant for comparison. The process of coating was carried out by the immersion method, which consists of completely submerge of the fabric in a bath containing the aqueous solutions of flame retardant products. After the coatings of the fabrics were characterized with microscopy (SEM) JEOL-6300 in order to analyze the effect of the flame retardant products on the fabric. The flammability tests for the samples with or without flame retardant products were carried out in order to observe their behavior under fire. 
The tension test too was made to the samples to observe the effect of the coatings on the mechanical properties. For tensile test were used the NMX-A-059-INNTEX, whereas for ripped test a NMX-A-109-INNTEX and for inflammability test the ASTM-D6413.

\section{Results and Discussion}

\subsection{Mechanical Properties}

\subsubsection{Tension Results}

After the use of the flame retardants the mechanical properties of the fabrics were improved or at least remained the same as compared with the fabrics without any treatment, because the retardants form a coated on the textiles, the better results for the tension test are those for the mix Borax/Hexametaphosphate of Sodium/Water in the warp and weft.

The results of tension test in original samples and after the treatment with different retardants are summarized in Table $\mathbf{1}$.

\subsubsection{Ripped test}

Only in two values the resistance to rip is equal to the original of the acrylic warp with the commercial retardant and with the mix of Borax/Hexametaphosphate of Sodium/Water as seen in Table 2. It is agreement with the values of elongation. The lost of elongation made the acrylic more stiffness and the sample lost resistance to rip.

\subsubsection{Inflammability}

The flame retardant capabilities of the textile fabrics before and after the use of the flame retardant products were investigated using the special textile methods for inflammability. The results of the inflammability tests after the use of different products are presented in Table 3.

From this table one can observe that the burning time of the fabrics treated with the solution based on Borax $\left(\mathrm{Na}_{2} \mathrm{~B}_{4} \mathrm{O}_{5}\right.$ $\mathrm{OH})_{4} \bullet 8 \mathrm{H}_{2} \mathrm{O}$ ) increased in several times in dependence on Borax concentration. The treatment with the solution Borax/Hexamephosphate of Sodium $\left(\mathrm{Na}_{16} \mathrm{P}_{14} \mathrm{O}_{43}\right)$ leads to the same results. So,

\begin{tabular}{|l|l|l|l|l|l|l|}
\multicolumn{7}{|c|}{ Table 1 Results of the Tension Test (Kgf). } \\
\hline & $\begin{array}{l}\text { Fiber } \\
\text { Original }\end{array}$ & $\begin{array}{l}\text { Commercial } \\
\text { Retardant } \\
\text { Pure }\end{array}$ & $\begin{array}{l}\text { Commercial } \\
\text { Retardant/ } \\
\text { Water 1:1 }\end{array}$ & $\begin{array}{l}\text { Borax } \\
100 \mathrm{~g} / 1\end{array}$ & $\begin{array}{l}\text { Borax } 200 \mathrm{~g} / \mathrm{l} \\
\text { Worax/Hexame } \\
\text { taphosphate of } \\
\text { Sodium }\end{array}$ \\
\hline Warp & 52.52 & 53.12 & 53.06 & 53.47 & 54.71 & 65.74 \\
\hline Weft & 46.15 & 46.12 & 47.12 & 47.83 & 51.62 & 63.03 \\
\hline
\end{tabular}

\begin{tabular}{|c|c|c|c|c|c|c|}
\hline & $\begin{array}{l}\text { Fiber } \\
\text { Original }\end{array}$ & $\begin{array}{l}\text { Commercial } \\
\text { Retardant } \\
\text { Pure } \\
\end{array}$ & $\begin{array}{l}\text { Commercial } \\
\text { Retardant/ } \\
\text { Water } 1: 1 \\
\end{array}$ & $\begin{array}{l}\text { Borax } \\
100 \mathrm{~g} / \mathrm{l}\end{array}$ & $\begin{array}{l}\text { Borax } \\
200 \mathrm{~g} / \mathrm{l}\end{array}$ & $\begin{array}{l}\text { Borax/Hexame } \\
\text { taphosphate of } \\
\text { Sodium }\end{array}$ \\
\hline Warp & 9.84 & 8.49 & 9.70 & 7.63 & 6.20 & 9.29 \\
\hline Weft & 9.81 & 6.66 & 7.31 & 7.63 & 5.36 & 5.68 \\
\hline
\end{tabular}

Table 3 Results of the Inflammability Resistance Tests (Sec.)

\begin{tabular}{|l|l|l|l|l|}
\hline & $\begin{array}{l}\text { Fiber } \\
\text { Original }\end{array}$ & $\begin{array}{l}\text { Borax } \\
100 \mathrm{~g} / \mathrm{l}\end{array}$ & $\begin{array}{l}\text { Borax } \\
200 \mathrm{~g} / \mathrm{l}\end{array}$ & $\begin{array}{l}\text { Borax/Hexame } \\
\text { taphosphate } \\
\text { of Sodium }\end{array}$ \\
\hline Warp & 8.62 & 99.71 & 147.93 & 157.85 \\
\hline Weft & 8.53 & 114.07 & 143.27 & 146.88 \\
\hline
\end{tabular}

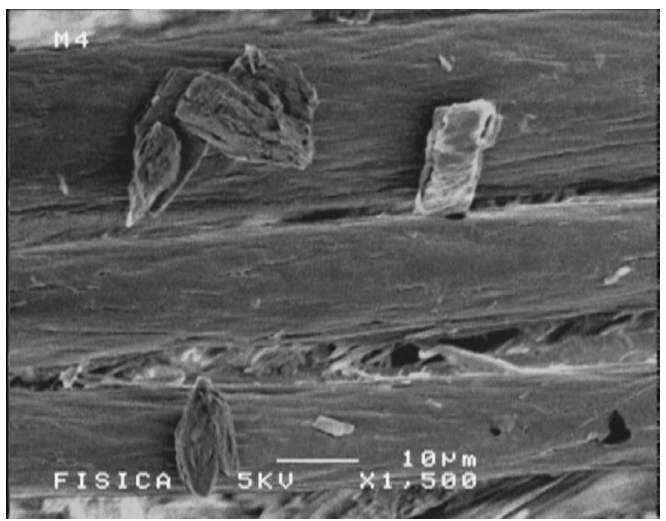

Figure 1. SEM micrograph of the sample coated with Borax 100g/l /Hexametaphosphate of Sodium to 100g/l (1000X).

these flame retardant products can stop the combustion of fabrics on certain distance before the sample with the commercial retardant product will be completely consumed. The possible explanation of such result is due to decomposition of Borax and liberation of water, which retards the fire propagation in the sample. This process takes place because of low melting point $\left(75^{\circ} \mathrm{C}\right)$ of Borax. For the fabrics after treatment with solution contained Borax and Hexametaphosphate of Sodium the same results were obtained. If Borax forms water at the moment of its decomposition then the Hexametaphosphate of Sodium, which is the compound contained phosphorus and oxygen, at the decomposition gives rise phosphoric acid $\left(\mathrm{H}_{3} \mathrm{PO}_{4}\right)$, which reacts with the hydroxyl groups released by the Borax producing of dehydration. The dehydrated materials, which were formed from the Borax, generated remaining carbon relatively fireesistant, which functioned like a barrier and inhibited the degradation and protected the material from the pyrolisis.

\subsubsection{Scanning Electron Microscopy}

SEM was used in order to observe how the flame retardants have been deposited onto coated fibers Figure 1 it can be seen the formation of small crystallites on the fiber surface after immersing in the solution with Borax. From this image it can be concluded that the covering processes of the acrylic fiber by two different retardant materials are different. At the same time Borax, also does not interact with the fiber chemical structure, however instead of the film formation crystallites grew on the fiber surface.

\section{Conclusions}

The flammability tests the fabrics with the prepared new flame retardant products showed very good results such as 8 seconds of combustion for the untreated fabric and 2 minutes for the fabric treated with the solution of Borax / Hexametaphosphate from Sodium /Water. This result shows the essential increase of combustion retardation time. The gained time space is very important as during these 2 minutes at a conflagration it is possible to save lives or to control the fire. The tension Test Resistance is better with the mix of Borax and Hexametaphosphate than the original Acrylic.

The scanning electron microscopy shows that the flame commercial retardant is deposited on the surface of the fabric as 
a thin film and the solutions based on Borax and Hexametaphosphate of Sodium were deposited in the form of crystals on surface. These coatings do not produce any new chemical species within the internal structure of the fiber.

\section{REFERENCES}

[1] J. Detrell, 1998 Comportamiento al calor de los materiales textiles. Tecnitex Documentación. Terrassa, España.

[2] I. Cuadra, A. Belkis, G. Infante, L. Beltrán, C. Melian, 2001 Estudio del comportamiento de la combustión de diferentes tejidos utilizados como ropas protectoras. Revista Latinoamericana de Tecnología Textil, 13, 37-45.

[3] K. Kandola, A.R. Horrocks, P. Myler, D. Blair, 2002. The effect of intumescents on the burning behavior of polyester-resin-containing composites. Composites: Part A, Applied science and manufacturing, 33, 805-817.

[4] M.J. Tsafack, J. Levalois-Grützmacher, 2006. Flame retardancy of cotton textiles by plasma- induced graft-polymerization
(PIGP) Surface \& Coatings Technology, 201, 2599-2610.

[5] M.J. Tsafack, J.Levalois-Grützmacher, 2007. Towards multifunctional surfaces using the plasma-induced graft-polymerization (PIGP) process: Flame and waterproof cotton textiles. Surface \& Coatings Technology, 201, 5789-5795.

[6] M.J. Tsafack, J.Levalois-Grützmacher, 2007. Plasma-induced graft-polymerization of flame retardant monomers onto PAN fabrics Surface \& Coatings Technology, 201, 3503- 3510.

[7] D. Weifu, Z. Xiaohong, L.Yiqun, W. Qingguo, G. Hua, G. Jianming, S. Zhihai, L. Jinmei, H. Fan, Q. Jinliang, 2006. Flame retardant nanocomposites of polyamide 6/clay/silicone rubber with high toughness and good flowability Polymer, 47, 6874-6879.

[8] E. Baysal, M. Altinok, S. Colak, K. Ozaki, H. Toker, 2007. Fire resistance of Douglas fir (Pseudotsuga menzieesi) treated with borates and natural extractives. Ioresource Technology, 98, 1101-1105.

[9] A. J. De Saja, M.A. Rodríguez, M.L. Rodríguez, Materiales, 2005. Estructura, Propiedades y Aplicaciones, Ed. Thomson. 